\title{
A VIEWPOINT ON THE DISPUTE AMONG ANTHROPOLOGISTS OVER RAGIALLY TARGETED POLIGIES IN BRAZIL
}

\begin{abstract}
Over the last few years the Brazilian government has moved towards introducing policies directed to the "Afro-Brazilian population". In addition, more than eighty public universities have introduced quotas that favour Afro-Brazilians and/or poor candidates. In a country which has avoided incorporating 'race' into the letter of the law and which has developed a now widely held self image as a country without clear racial boundaries such measures have provoked a heated national debate. Anthropologists are prominent amongst the proponents and critics of racial quotas. This article seeks to present the arguments on both sides of the debate and to speculate on why anthropologists have become so seriously divided on this issue.
\end{abstract}

\section{Um ponto de vista sobre o conflito entre os antropólogos relativo às políticas com base nas raças no Brasíl}

Ao longo dos últmos poucos anos o governo brasileiro tem se posicionado a favor de políticas publicas dirigidas para «a população afrodescendente ». Além disso, mais de oitenta universidades públicas têm introduzido cotas que favorecem negros e/ou candidatos pobres. Num país que tem evitado incorporar 'raça' na letra da lei, e que tem desenvolvido uma auto-imagem largamente aceitada de ser um país sem fronteiras «raciais » claras, essas medidas tem provocado um debate nacional acirrado. Antropólogos são proeminentes entre os proponentes e críticos das cotas raciais. Este artigo procura apresentar os argumentos de ambos os lados do debate e especular sobre porque os antropólogos se tornaram tão seriamente divididos em relação a esta questão.

\section{Un point de vue sur le conflit opposant les anthropologues au sujet des politiques visant les races au Brésil}

$\mathrm{Au}$ cours des dernières années, le gouvernement brésilien a commencé à introduire des politiques destinées à la "population afro-brésilienne». En outre, plus de quatre-vingts universités publiques ont introduit des quotas qui favorisent les Afro-brésiliens ou les candidats pauvres. Dans un pays qui a évité d'incorporer la « race » dans la lettre de la loi et qui a développé sa propre image désormais largement connue de pays sans frontières raciales claires, de telles mesures ont provoqué un débat national passionné. Les anthropologues jouent un rôle de premier plan parmi les initiateurs et les critiques des quotas raciaux. Cet article cherche à présenter les arguments des deux côtés du débat et à spéculer sur la raison pour laquelle une si grave division a séparé les anthropologues sur ce sujet.

\footnotetext{
"Social scientists must give careful consideration to the effect of attempting to measure discrimination in Brazil by imposing an emically invalid categorization of color-race groupings modeled after the US racial caste system. Racial discrimination is widely perceived as a matter of civil rights. But it is also a matter of civil rights that individuals be permitted to categorize themselves
} 
and their children according to their own sense of identity. Brazil may be no closer to racial democracy than other countries, but its system for establishing racial identity has many features from which the world has much to learn."

Marvin Harris et al., "Who are the Whites?: Imposed Census Categories and the Racial Demography of Brasil”, Social Forces, 72.

$66 \mathrm{~W}$ e wish to affirm, and truly with considerable pride, our condition as a multi-racial society and that we have great satisfaction in being able to enjoy the privilege of having distinct races [raças distintas] and distinct cultural traditions also. In these days, such diversity makes for the wealth of a country." [My emphases] These words were not pronounced by the President of South Africa, nor even a multicultural zealot in Great Britain or the US. Rather they were spoken on Brazil's Independence Day in 1995 by the recently elected president, sociologist Fernando Henrique Cardoso. What could be further from the mixture idealized by Gilberto Freyre than the concept of distinct races? What could be further from the optimistic words of Marvin Harris in the epigraph to this essay? If anything, rather than Brazil bringing something positive to the world it was as if it had instead considered itself lacking, looking askance at its own 'emic' system and imposing an "emically invalid categorization of color-race groupings modeled after the US racial caste system".

Since pronouncing these words, the Fernando Henrique government, and more assiduously, that of Luís Inácio Lula da Silva have presided over the introduction of racially targeted affirmative action.

\section{The issue}

The Lula administration which came to power in 2002 and which has developed strong relations of alliance to "the social movement", gave greater salience to the issue of race by creating the Special Secretariat for Policies for the Promotion Racial Equality (SEPPIR) which was charged with promoting "the equality and protection of the rights of individuals and ethnic and racial groups [sic] affected by discrimination and other forms of intolerance, with emphasis on the black population", in cooperation with public and private institutions in Brazil and abroad $^{2}$.

This tiny Secretariat with a staff of less than forty has been extremely active in making itself felt in various ministries and in state and municipal governments, encouraging policies directed to negros principally in the fields of health and education. It has also lent its weight to two governmental projects which if implemented would definitively install a bipolar racial taxonomy in Brazil. The first is a Bill which seeks to implement racial quotas in all federal institutions of higher learning (PL 73/1999) and the second is a Bill which proposes the establishment of a Statute for Racial Equality (PL 3.198/2000).

\footnotetext{
1 The phrase "o movimento social" is intoned whenever government wishes to assert the "popular" nature of any particular policy.

$2<$ www.planalto.gov.br/seppir/>, accessed on 4 September 2006.
} 
The first bill which is still to be debated in Congress extends racial quotas to all federal universities. Each university would reserve places to Indians, Blacks and Whites in accordance with their statistical distribution in the state where the university is situated. In effect, it will oblige all candidates for federal university places to define their colour/race. The Statute of Racial Equality is far more wide-ranging in its aims, containing an Introduction and eleven chapters, covering rights to health, education, belief, employment and fair pay, justice, and representation in the media ${ }^{3}$. Throughout the document Brazil is presented as a country of two races: on the one side the 'Afro-Brazilians', "people who classify themselves as such and/or as negros, pretos, pardos or an analagous definition"4 (Paim 2006: 13) and on the other, un-named but logically present, are the 'whites' (Grin 2006). Interestingly enough there is no reference in this document to the Indians. The cover which is a photograph of a very well nourished black family with 'ethnic' hairstyles well signals its contents.

If brought into law the Statute will oblige all citizens of Brazil to declare their 'race or colour' at just about every step in their lives.

Other significant legislation introduces the obligatory teaching of the History of Africa and Afro-Brazilian Culture in schools (law n 10 639, 2003) whose curriculum lays to rest the notion of a country of genetic and cultural mixture in favour of a persistent state of conflict and tension between blacks and whites.

Racial quotas and the Statute for Racial Equality are part of a much wider process of government sponsored change which aims to dismantle the old notions of hybridism and the anthropophagy of the modernist movement in favour of a multicultural society made up of discrete races and ethnic groups.(Maggie 2008). Yearly more Indian groups affirm their identity in Brazil's northeast above all, and legislation guaranteeing land rights to descendants of runaway slave communities (quilombos) has led to a burgeoning of such communities all over Brazil. Diversity has become a shibboleth proclaimed by myriad social movements as they demand recognition and material reward from government. It is as though class had given way to race and ethnicity as the principal concept for understanding Brazil.

Anthropologists have been in the forefront of the undoing of Brazilian mixture, ranging from a post colonial theoretical justification of such diversity, presented almost as an ontological good in itself, to the humble producers of reports (laudos) attesting to the legitimacy of such ethnic and racial demands. These anthropologists have become the cartographers of difference, drawing boundaries around discrete ethnic and racial 'communities'. What president Getúlio Vargas joined together during the Estado Novo from 1937-45 with fire and the sword (Seyferth

\footnotetext{
3 The chapters are: "On rights to health"; "On rights to education culture, sport and leisure"; "On rights to freedom of conscience and belief and on the free exercise of religious cults"; "On the financing of the promotion of racial equality"; "On the rights of the Afro-Brazilian woman"; "On the rights of descendents of maroon community to their lands"; "On the labour market"; "On the quota system"; "On the media"; "On permanent watchdogs in legislative assemblies"; and "On access to justice".

4 "As pessoas que se classificam como tais e/ou como negros, pretos, pardos ou definição análoga".
} 
1996), the anthropologists and social movements are tearing asunder with the promise of recognition, land and specifically targeted social services.

A parenthesis. Many years ago, when the military government threatened to de-Indianise some indigenous groups I accompanied the then president of Brazilian Anthropological Association (ABA), Eunice Durham, on many litigious meetings with the ruling generals. Jokingly, Eunice suggested to me that we set up an anthropological organization to attest the authenticity of Indian groups for a small fee. That joke has become reality in post military democratic Brazil. End of parenthesis.

But let me talk only of the racial issue. The original initiatives in the direction of affirmative action were taken by politicians. The first racial quotas in universities were introduced to the state of Rio de Janeiro at the hands of a humble state deputy, José Amorim who had no formal links to the black movement. Prior to the introduction of these first quotas, the black movement was divided over the issue. Once a reality, however, the black movement rallied around them and then rapidly became a sacred symbol of the movement and its allies, among them a number of anthropologists. Those of us who took a more critical stance observed that most of what was being introduced seemed to pass through state assemblies, and university councils with little or no debate ${ }^{5}$. Considering that the incorporation of 'race' (and just two of them) into public policy represented a major, even revolutionary change in Brazil's republican tradition we argued that much serious debate was a fundamental necessity. This led us to write for the press, publish a book of critical essays and interviews (Fry et al. 2007), and to sign open letters to Congress and the Federal Supreme Court, each of which provoked opposing manifestos also signed by many social scientists, anthropologists among them ${ }^{6}$.

The point of this paper is to look at the contrary positions and to ask why some went in one direction and other in another. In a sense, then I attempt a meta anthropology.

But of course this is impossible since I am an actor in the story I narrate. Be prepared, then, for an ill concealed parti pris. A few words on my own perspective are therefore mandatory.

${ }^{5}$ The top down implementation of racial quotas has been noted by Mala Hтun 2004.

${ }^{6}$ On May 30th 2006, an open letter (carta pública) to congress deputies signed by opponents of racial quotas, was delivered by two social scientists and two members of the Black Socialist Movement to the president of the congress. It requested that the bills on racial quotas and the Statute of Racial Equality be rejected. On July 3rd enthusiasts of the racial quotas, again activists and social scientists delivered a "Manifesto in favour of quotas and the Statute of Racial Equality" to the same president. When it became clear that the issue of quotas would soon become a constitutional issue, the critics of quotas delivered another document to the Supreme Court on April 28, 2008. This was followed by a further manifesto on the part of the proponents who delivered it on May 13th, 2008. Many of the signatories of both documents were social scientists. Of the 113 who signed the first letter, 65 or $58 \%$ defined themselves as social scientists, either sociologists (19), anthropologists (16), economists (4), political scientists (10) or historians (6). The Manifesto continued to be signed, but from one list of 152 signatories, 68 or $45 \%$ declared themselves social scientists, either anthropologists (30), sociologists (16), historians (13), political scientists (7) or economists (2) < http://desoc.blogspot.com/2006/07/manifestoem-favor-da-lei-de-cotas-e.html>, accessed on 30 January, 2009. 
When I first arrived in Brazil in 1970 to help inaugurate social science teaching and research at the State University of Campinas (Unicamp), São Paulo, I think it is true to say that in São Paulo at least, the anti-freyrean narrative was dominant. And I had little difficulty in adhering to it having already encountered Gilberto Freyre at his political worst in a shameful piece of propaganda for Salazar's policies in Africa (Freyre 1961).

But as time has gone by and having worked for the Ford Foundation both in Brazil and in post colonial Zimbabwe, I have become less sanguine in relation to the supposed virtues of racially targeted policies however well intentioned they may be. In Brazil, I always found it embarrassing to ask grantees to classify themselves by 'gender' and by 'race'. After all we wanted to know people's sex, not their gender! And when it came to race (with only two categories), the grantees and I had a tricky job trying to force the US system of classification over Brazil's 'emic' categories. But I found Zimbabwe even more worrying; in 1989, nine years after independence, it was almost as racially segregated and conflictive as it had been as Southern Rhodesia which I had known as a young researcher in the 1960s. However critical I had been and continue to be of racial prejudice and discrimination in Brazil, I could only admire Brazil's ability to keep race off the statute book.

\section{Three situations}

In this essay I have chosen to look at three social situations in which anthropologists have taken opposite sides on the implementation or attempts at implementation of racial quotas: the University of Brasilia; the Federal University of Rio Grande do Sul; and, finally, Brazil's flagship anthropology graduate program, the Post Graduate Progamme in Social Anthropology of the National Museum of the Federal University of Rio de Janeiro.

\section{The University of Brasília (UnB)}

Sometime in 1998, I do not remember exactly when, I received a telephone call from my anthropologist colleague José Jorge de Carvalho of the University of Brasília. He told me that a young black graduate student from Bahia, Arivaldo Lima Alves, had failed an obligatory course, that he might lose his scholarship and that it was clearly a case of racism. Would I pronounce? I said the obvious; that accusations of racism were akin to accusations of witchcraft, that I found it difficult to imagine that such an accusation had any foundation and had therefore nothing to say. Indeed, I later discovered that the professor in question, rather strict it would appear, had also failed a couple of other students, both of lighter complexions. The Department of Anthropology reviewed Arivaldo's term paper, endorsed the professor's mark and repudiated the accusation of racism (Ribeiro 2006: 78)7. But José Jorge de Carvalho and his also anthropologist wife Rita Segato

7 "No DAN [Departamento de Antropologia] nunca ficou provado e/ou aceito que a reprovação do doutorando Rivaldo Lima Alves tenha tido motivação racista. A não ser Jorge Carvalho e Rita Segato, nenhum outro professor do Departamento de Antropologia corroborou esta versão que foi transformada em 'Caso Ari', um ícone de um suposto racismo acadêmico", Ribeiro 2006. 
took the case to the highest instances of the $\mathrm{UnB}$ and in the end the University Council of Teaching, Research, and Outreach "recognised that the grade Ari had received was unjust and altered the professor's grade" (Segato 2006: 276). In Carvalho's and Segato's narrative, the "Caso Ari" as this event came to be known (Carvalho 2005: 238, Segato: 275), made them aware of racism within the university and led to their drafting a proposal to introduce racial quotas in the UnB, which was presented formally in 2002 (Carvalho \& Segato 2002). The "Ari Case" ("Caso Ar") had become elevated to the status of mythical charter for racial quotas in the University of Brasilia.

The proposal was based on statistical data on racial inequality. It began by affirming that the "racial composition of the university is a perfect reflex of the history of Brazil after Abolition", during which no effort was made to compensate ex-slaves while government immigration policy brought in Europeans who brought severe competition to the labour market. (Ibid.: 4) "The blacks, who represent $45 \%$ of the population of the country, make up only $2 \%$ of the university population; the whites and the yellows, who represent $54 \%$ of the population hold $98 \%$ of the places in the universities" (Ibid.: 29). The Brazilian census bureau recognises five possible categories to the question "What is your colour/race?": black (preta), brown (parda), white (branca), yellow (amarela) and indigenous (indígena). Since racial quotas logically require but two races (either you have a right to the quotas or you don't), the pardos must become either whites or blacks. Although Carvalho \& Segato did not cite their sources for these figures it is interesting to note that when looking at the universities, they joined together 'brancos' and 'pardos' to reach the startling figure of $97 \%$ white students in Brazilian universities. When describing Brazil as a whole, however, they lumped together the pardos, and the pretos to form the category negro 'blacks' (45\%), hence exaggerating the degree of exclusion of black students. These spurious figures (government statistics reveal that the average percentage of blacks and browns in Brazilian universities as a whole is nearer $28 \%$ ) continue to surface in most justifications for quotas.

Having demonstrated exclusion, the quotas were proposed as the logical solution. $20 \%$ of places at the University of Brasília should be reserved for 'negros' for a period of ten years to compensate for disadvantage and also contribute to the formation of a racially conscious black elite. "We emphasise that this is an emergency programme designed to accelerate the formation of a black elite which will be able to contribute to the formulation of new policies designed to eliminate for once and for all the problem of racial inequality and exclusion in Brazil" (Ibid.: 22). Why 20\% and not any other percentage was not discussed.

On the knotty question of who would qualify for the quotas, they followed the example of the state universities of Rio de Janeiro suggesting that the candidates themselves would declare their racial "identity". As events would have it, the question of who was black and who was white became a central issue in the case of the University of Brasília. A prominent black activist, Father Davi Raimundo dos Santos, had severely criticized this method in the state universities of Rio, claiming that many 'whites' had declared themselves 'black' in order to benefit from the quotas. Against the advice of Carvalho, the administration of the University of Brasília opted therefore for a system whereby candidates would declare their 'race' but at the same time have their photographs taken which 
would be examined by a commission composed of a student, a sociologist, an anthropologist and three representatives of Brazil's Black Movement.

This gave rise to a critical article written by sociologist Marcos Chor Maio and biological anthropologist Ricardo Ventura Santos who describe how in June 2004, candidates for the University of Brasília's first entrance examination with racial quotas formed two queues; one for those competing for the $20 \%$ of places reserved for negros who had their photographs taken, and one for the rest (Maio \& Santos 2005).

What Maio \& Santos aptly called the 'anatomical commission' rejected 212 out of 4,385. Thirty-four of these complained, and were interviewed by a second 'psychological' commission, composed of university teachers and members of non-governmental organizations, who were charged with finding out who was really black through in depth interviews to find out whether they had strong links to 'black values and culture'. One young man said afterwards that they asked him whether he had belonged to the Black movement and if he had ever had a mulata girl friend. In the end, only 13 of the 34 were denied a black identity.

In 2007 this process produced an embarrassing situation for the University of Brasília when a young man was given the right to compete for a racially reserved place while his identical twin brother was declared white. In the end, the psychological commission declared them both black and José Jorge de Carvalho was able to state: "You can't stop a policy because of a mistake".

What he was reluctant to recognise was that discrimination is based on how the individual is seen by others and not how she/he sees herself/himself. That is why the photographs and commissions make sense for the black activists who wish to benefit people who have potentially suffered from discrimination not because of their desired identity but from the way their appearance is interpreted by others. As I argued at the time, the photographs are a logical conclusion of the premises of the policy (Fry 2004). After all, as we have known at least since Oracy Nogueira's seminal article of 1954, Brazilians classify more by appearance as a mark of African descent than by descent itself (what he called origin) (Nogueira 1959).

Maio \& Santos describe the process as a "racial pedagogy, converting pardos and pretos into negros". In particular they were concerned to understand the presence of the anonymous anthropologist on the "racial tribunal", hypothesizing that the presence of such a 'racial specialist' might provide the 'scientific' legitimacy that the selection required.

Far from legitimizing the process, however, the presence of an anthropologist on the team may have been important in spurring the Commission of Racial and Ethnic Relations of the Brazilian Anthropological Association (Crer-ABA) to issue a very critical note, insisting that individuals must have the right to determine their own identity. To deny this would be to "ignore the conceptual framework of the social sciences, and, in particular, that of social and biological anthropology" (Maio \& Santos: 42). Maio and Santos drew parallels between the racial tribunal at the University of Brasília and the role of physical anthropologists in the early 20th century, showing how modern (molecular) biological anthropology has brought increasing evidence for the non-coincidence between phenotype and genotype (questioning in this way the category 'afrodescendente'), and end their 
article concluding that "in the anti-racist battle, in which 'race' is understood as a social construct and as an instrument of liberation from racial oppression with the backing from the state, there is a risk of moving towards essentialized categories, fixed, determined by the normative power of the law, and to the designs of public policy" (Maio \& Santos: 50).

Among those who wrote in favour of the Maio and Santos article, a number agreed with the authors that Brasília was not an exceptional case; rather an exemplary one. Anthropologist Bernardo Lewgoy commented that "to use official racialization to combat racism is more or less like fighting a fire with gasoline" (Lewgoy 2005). Luiz Fernando Dias Duarte on an even more sombre note which also evoked impending disaster: "the crucial point in the perverse dynamics unchained during this process is without doubt the reduction of the complex issue of inter-ethnic relations in our society to 'racial essentialization'. The authors could not have been more precise in their claim of the devastation that the re-creation of an ideology of racial substances and their transformation in state policy might provoke in our ideas of the universalization of Brazilian citizenship" (Duarte 2006: 99). In his brief but dense essay, Duarte exposes the dangers of transposing the romantic argument of difference, intensity and totality to collective political action: "[The] fact that geographical ghettos and Bantustans are not being created here should not deviate from the central recognition that the substantialisation of ethnic difference is a cultural ghettification, as perverse as that which employs barbed wire" (Ibid.: 101).

Central also to the discussion was the biological critique of race. In order to contrast their constructivist argument Maio \& Ventura Santos evoke recent genetic research in Brazil. Three geneticists joined the fray lamenting the 'racial tribunal' and drawing attention to their own research that has confirmed the high rates of African, Amerindian and European genes in most Brazilians which has further imploded the biological reality of 'race' (Bortoloni 2005, Pena 2005, Salzano 2005).

Those who criticized, in particular Carvalho \& Segato, concentrated on what they saw as factual errors relating to the political process leading up to the adoption of quotas within the University of Brasilia and what they claimed to be the authors' use of anthropology to conceal political and ethical opinions. They reiterated the need to compensate for slavery and continued discrimination. None of the critics questioned Maio's \& Santos' analysis of the selection procedure as a racial tribunal, nor their argument that the quota system risked essentializing racial categories. It was as if the principal argument of the critics - that the quotas were a sort of self-fulfilling prophecy - simply did not need attention. José Carlos dos Anjos, however, questioned the possibility of combating race without naming it:

"What is at stake is the possibility of constituting dispositives which are functional to de racialization but which are not merely rhetorical. Since racialization in Brazil did not only have effects of representation, the practices which can descontruct it may not be effective if limited to the dominion of a [de] racial pedagogy." (Anjos 2005: 235)

Lívio Sansone, ambiguously straddled the divide between the two positions. Affirming his approval of affirmative action, he argued that it would not bring about a racially polarized Brazil because a 'local' Brazilian interpretation of an 
internationalized bipolar racial schema would somehow defuse it. Minimizing the impact of the quotas, Sansone wrote: "Inter-racial cordiality - both as myth and reality - is still worshiped as something too precious to be thrown away" (Sansone 2006).

Anthropology was then divided between two quite distinct positions. Both could define their positions as constructivist (no one in their right mind would deny that races are socially constructed), but while those in favour of quotas affirm the need to employ racial categories to combat inequality and injustice, those against them argue that linking the distribution of public goods and services to racial identities is a way of (a) instituting a Brazil of two distinct racial categories, and (b) enshrining them in law. The proponents believe that 'race' as a sociological reality cannot be denied, while the opponents understand that 'racial' inequality is founded ultimately in a belief in the existence of races. Public policy must then be designed to eradicate this belief or, at least not reinforce it. What characterises the discussion in the case of the $\mathrm{UnB}$ is that the less radical constructionists cannot or will not take seriously the position of the radical ones.

\section{The Federal University of Rio Grande do Sul}

During the first semester of 2007, a group of professors and students, supported by the Rector, proposed the implementation of racial quotas. The argumentation followed that of the $\mathrm{UnB}$, arguing from the statistics of inequality to quotas.

Unlike the UnB document, however, the figures were carefully presented and show that the proportion of black students (again, pretos and pardos were conjoined into one category - negros) in the university was $6.35 \%$, about half of the $12,8 \%$ in the State of Rio Grande do Sul. A considerable difference, to be sure, but nothing compared to the Carvalhos' figures for Brasília! The document argued that quotas would be temporarily and circumstantially necessary to combat inequality, but their proportion would grow over time from $10 \%$, or $2.8 \%$ less than the proportion of 'negros' in the State of Rio Grande do Sul to 20\% in 2010 or $7.2 \%$ more. Candidates would themselves opt for quotas or not, while a Special Verification Commission made up of representatives of faculty, students technical and administrative staff and after 2009 at least one quota student, would examine the applicants in the manner of the UnB commissions. In addition, and distinctly from the UnB, the proposal included the same proportions of university places were to be reserved for those candidates who had studied in public schools.

The debate that this provoked had as principal antagonists two anthropologists who had participated in the debate over the Maio Santo article, José Carlos dos Anjos and Bernardo Lewgoy.

Bernardo Lewgoy became the most active critical voice within and without the university thus becoming the butt of the angry promoters of quotas, especially after writing an article in the local newspaper, Zero Hora, on June 14 entitled "No to quotas in the UFRGS*" (Lewgoy 2007a). In this article, he argued that the educational inequalities between pretos, pardos and brancos were due not so much to discrimination but to differential access to education of quality. Bringing to

* Editor's note: Universidade Federal do Rio Grande do Sul. 
bear his constructivist position, he argued that racial quotas would "bring to Brazil the seeds of racial hatred, as yet unknown to us. In effect, inequality of access to the university is a social and not a racial problem and must be combated with massive education in income and education and not through policies of racial preference" (Ibid.). He wrote "Race' only exists in the eyes of racists and racialists. To wish to combat racism by making it official as a concept is a mistake for which we will pay a very high price if nothing is done to stop it".

Lewgoy's article was met with derision. It was stuck on the walls of the Institute of Philosophy and human Sciences with the words "Bernardo Lewgoy ignores slavery" and "Bernardo Lewgoy wishes to rehabilitate Gilberto Freyre".

Bernardo received support from his philosopher friends who insisted in his right to opinion, but not from the anthropologists. Claudia Fonseca, for example, who presides over the university's Nucleus for Anthropology and Citizenship published on the internet a text entitled "Why not quotas?". In it, she insisted on the existence of racism in Brazil, and on the need for the university to take a lead in combating racial exclusion. But she also added an ad hominem attack. Referring to the argument that the principal reason for the relative absence of blacks and the poor in the universities is due to the low quality of public education, (Lewgoy's argument) she wrote: "Please pardon the ironical tone of this text - but I am truly amazed at these arguments, for, in my view they reveal a profoundly racist logic".

A far stronger and impassioned attack marked by irony and sarcasm came from José Carlos dos Anjos in a text entitled "If races don't exist, you can't deny that they insist"10. His argument was less to defend quotas as such and more to show the extent of racism in Brazil. Parting from his perspective as a black activist (he is from the Cape Verde Islands), he accused the anthropologists of not listening to those 'natives' who can testify to racism. Beginning with José Jorge's de Carvalho's statistics (ignoring those presented in the UFRGS' own proposal), he affirmed that "In Brazil racial condition constitutes a factor of privilege for whites and exclusion and disadvantage for non whites". But his principal point was that even though the biologists have deconstructed race as a scientific concept, that in itself is not enough to do away with races and racism: "Light weight anti racism does not perceive that the inexistence of race cannot be achieved by a magical scientific enunciation. It is not because scientists say that races do not exist that they then cease to exist socially". Then, in an indirect attack on our books "The persistence of race" (Fry 2005) and "Dangerous Divisions" (Fry et al. 2007), dos Santos asks rhetorically and sarcastically what those who fear the persistence of race really fear: "What subjective dispositions might be behind this devastating wave of our sublime anti racist humanism"? His hypothetical answers follow:

${ }^{8}$ Anthropologist Gilberto Freyre, often (wrongly) supposed to have coined the terms 'racial democracy', is considered by the Black activist movement iconic of those who would argue that Brazil lacks racial antagonisms.

9 "Porque não quotas?", <www.enlacers.com.br/textos/artigos/porque_nao_cotas.pdf>, accessed 10 July 2009.

10 "Se raças não existem, é inegável que insistem!", <http://ufrgsprocotas.noblogs.org/ post/2007/06/22/se-ra-as-n-o-existem-ineg-vel-que-insistem>, accessed 10 July 2009. 
"Is it that they fear that our generous racial cordiality will not resist the test of equalling the numbers of blacks and whites in the university? Might it be that the national patrimony, which is the myth of racial democracy, is not good enough even to sustain a new moral disposition which demands and challenges that blacks live together with whites as soon as possible in reasonable number on our campus? Could it be that they think that whites will not be able to live together with Indians in anything other than the researcher-object relationship? [...] At bottom, these ultra humanist intellectuals, may perhaps agree that this racial-hate-white-beginning could be justified by the injustice of the 'non meritocratic entrance of blacks'! Maybe they fear the as yet untested potential of their own racial hatreds. They, so humanist!"

After a brief pause to note that the history of Jews cannot necessarily be compared to that of blacks (probably indirect reference to Lewgoy who is Jewish), he ends pointing to the terrible irony of black activists who suffer from racism being accused of racism themselves. "If real racism was difficult, now we Blacks live the tragedy of non-existent racism like a band of paranoid racists. The cosmopolitical problem is that this band is just too big for the mania to be resolved in a psychiatric institution that is not already in another world".

Far be it from me to hypothesise on the subjective dispositions of José Carlos dos Anjos or the logic of Claudia Fonseca, or, like them, to racialise the debate itself! Or, as Bernardo Lewgoy put it

"You disagree with me, so therefore you are a racist! A manicheistic syllogism if ever there was one, but one that tires with the monotony of its repetition. [...] I don't know whether those who disagree with me are sexually repressed or suffering from delirium tremens, nor do I know how many Caucasian or Asian genes they may have. Might it be that we should to a DNA test and subject ourselves to a Racial Tribunal to be able to participate in a debate which is of interest to all?" 11

Such was the efficacy of these ad hominem attacks that many professors and students who were critical of quotas preferred to remain silent. As Bernardo Lewgoy commented to me at the time:

"What hurts me is that the students who are critical of the quotas are silenced by the fear of replying to the pro quota shock troops on the discussion lists where the only thing they don't say is that I am a saint. I ask of my cowardly student friends how can someone fear to question another? Fear of being called a racist and so as not to tell me other adjectives which are used to describe me. [...] Since what has arisen is moral of a victim in search of justice emotionalism without control has taken over. It is extremely difficult to discuss the matter without being accused of being a racist. Imagine, me of all people, Jew and anthropologist, racist. This really upsets me."

In the end, Bernardo and his few allies lost the battle for quotas but at least won the battle against the racial tribunal, having written an article entitled "A racial tribunal for the UFRGS?", redolent of Maio's \& Santos' article on the University of Brasília (Lewgoy 2007b), which likened the Special Commission for Checking the Documents of candidates for quotas, to those scientists and bureaucrats who decided who should be eliminated in Nazi Germany.

${ }^{11}$ Personal communication, 23 June 2007. 


\section{The National Museum}

Three months after racial quotas had been approved at the UFRGS, a group of 41 students of the Post Graduate Program in Social Anthropology of the National Museum of the federal University of Rio e Janeiro launched a document entitled: "A policy of affirmative action: a proposal for the entrance of Indians and Black to the PPGAS - National Museum (UFRJ)". In it they propose the creation of extra places for Indians and Blacks in order to compensate for past suffering and contemporary exclusion.

The students' project owes its first inspiration to José Jorge de Carvalho who spoke to the issue in the Museum in 2006. As in similar documents it begins with statistics on racial inequality for Brazil as a whole and the PPGAS itself.

Anticipating those critics such as Luiz Fernando Dias Duarte who is a member of the PPGAS faculty who argue that quotas essencialise and mortally wound a universalism which is appropriate to modern democratic societies, the document goes on to deny that quotas bring about division, rather that they "contribute to avoid that the racial segregation verified in Brazilian society ceases to reproduce itself in an increasingly accentuated way in academic practice". It argues that quotas are a way to bring about the ideal of universalism, suggesting that present methods of recruitment "have contributed to the racializing profile which institutions of higher learning have (re)produced and propagated, including graduate courses". It is also claimed that the presence of Indian students (and not the Blacks for some reason) will transform the "mechanisms of the production of knowledge".

In reaction to this document, Luiz Fernando Dias Duarte circulated a text "Why I am against the 'affirmative action' movement in relation to the so called 'afro-descendentes' in Brazil". The bulk of the document lists the eight fallacies on which, he argues (and I agree) the policy of quotas is based:

1. The fallacy of the existence of a clear frontier between black and white "segments";

2. The fallacy of confusing the irrefutable presence of colour discrimination in Brazil with its localization within a particular group (the 'whites'), "when in fact prejudice is distributed along the capillaries of society so that it cannot be combated by favouring one group and prejudicing another but by institutional and ideological activities with an increasingly universal (not particularistic) message such as has been sought after with the criminalization of racism".

3. The fallacy of the confusion between colour prejudice and socio-economic exclusion: "a policy designed to empower segments defined by their 'colour' may eventually bring this about for a few social subjects, but it can bring about the effect of reinforcing 'prejudice' by reifying into delimited 'segments' that which has habitually been the subject of complex social and symbolic negotiation".

4. The fallacy that the contemporary so called white segment has inherited the responsibility of its ancestors for slavery and for the absence of post abolition policies.

5. The fallacy that what is good for the US is good for Brazil. 
6. The fallacy that entrance to the university will bring about the "inclusion" of those who suffer discrimination. The real problems are far more serious and "below". Those who are able to sit university entrance exams are a small relatively privileged minority of all colours. Maybe it is a good idea to encourage social bourgeoisification, but this should not be concealed behind the rhetoric of the inclusion of the discriminated masses.

7. The fallacy that discrimination may be combated through university entrance. He cites sociologist Carlos António Costa Ribeiro who shows that the factor 'race' kicks in after the university due to the pre-eminence of prejudice in the higher strata of society.

8. The fallacy of suggesting automatic success to candidates without the technical expertise to follow a very specialised course.

In consequence, Luíz Fernando Duarte refuses to proceed to two 'betrayals', invoking two loyalties: to what he understands to be the tradition of anthropology and to the people he has studied for many years:

1. Betrayal of the tradition of the discipline of anthropology of the relativization of the substantialization or essencialization of social constructed categories (even the politically correct ones); even more in the case of 'race', whose naturalization had such disastrous implications in the history o four culture;

2. Betrayal of the memory of the identity of all my 'informants', friends for thirty years of field work in diverse working class suburbs, people of all colours, who suffer equally the severe obstacles to their dreams and aspirations: I cannot imagine them being forced to see the "lighter" of their children being passed over in their access to whatever public goods of this country in favour of those who seem 'darker'.

A meeting was held to discuss the project but the discussion was put off sine die. I gather that from time to time the subject reappears. The fact is that faculty are divided on the issue, some signing documents issued by the critics of quotas, others those written by their proponents. So far as I know, however, only three have written either in favour of quotas, Otávio Velho (2007a, 2007b) and Eduardo Viveiro de Castro (Sztutman 2008), or against the critics of quotas, Márcio Goldman (2007).

Goldman has argued that the critics of quotas are unable to listen to the black movement. This is hardly relevant, since we have studiously not criticised black activists as such but the enshrinement of their desire in the laws of the state. Velho and Viveiros de Castro identify racial quotas with a praiseworthy move towards cultural diversity on the part of the Brazilian state. In an article that first appears in the newsletter of the University Trades Union of the Federal University of Rio Grande do Sul at the time of the implementation of quotas there and later published in a magazine of wider circulation, Velho develops a long rather post modernist argument in which he questions the naturalization of 'universalism'. Claiming that universalism is a result of coloniality, he argues in favour of a society which is a 'federation' of discrete and diverse ethnic groups, hence specific policies to diverse segments. Viveiros de Castro sees racial quotas as a 
component of cultural diversity (defined as positive): "[For the state] to promote cultural diversity is, for example, to implement a policy of positive discrimination, that is, quotas for blacks [negros] in public universities" (Sztutman 2008: 254).

\section{Discussion}

All the anthropologists concerned are at least unanimous in recognizing race as a socially constructed category. The difference is that while the critics of quotas fear that they will contribute to the maintenance of racialised thinking and practice by imposing a bipolar racial classification on all citizens, the proponents either ignore this argument, or affirm that it is necessary to recognise the 'social reality' of race to combat inequality. Ian Hacking has this to say about social construction:

"Social construction work is critical of the status quo. Social constructionists about X tend to hold that: (1) X need not have existed, or need not be at all as it is. X, or $\mathrm{X}$ as it is at present, is not determined by the nature of things; it is not inevitable. (2) $\mathrm{X}$ is quite bad as it is. (3) We would be much better off if $\mathrm{X}$ were done away with, or at least radically transformed. A thesis of type $(\mathrm{I})$ is the starting point: the existence or character of $\mathrm{X}$ is not determined by the nature of things. $\mathrm{X}$ is not inevitable. $\mathrm{X}$ was brought into existence or shaped by social events, forces, history, all of which could well have been different. Many social construction theses at once advance to (2) and (3), but they need not do so. One may realize that something, which seems inevitable in the present state of things, was not inevitable, and yet is not thereby a bad thing. But most people who use the social construction idea enthusiastically want to criticize, change, or destroy some $\mathrm{X}$ that they dislike in the established order of things." (Hacking 1999: 6)

Taking Hacking's X to be 'race', it would appear then that both sides in the dispute agree that $\mathrm{X}$ need not have existed, or need not be at all as it is. Where they differ is that the proponents of racial quotas may proceed to theses 2 and 3 , but only in the long term. They presumably believe that racial consciousness is not a bad thing at all, or else they believe that such consciousness might have temporary benefits; a sort of 'strategic essentialism' proposed by Gayatri Spivak, but later disowned by her (Spivak 1990). They appear to believe that Brazil is ontologically made up of blacks and whites. From there on the step to essentialization is a short one. Having established this truth (which is the truth of the black activists, of course) they then go on to justify quotas as a temporary policy to compensate for the suffering of one category at the hands of the other.

Their opponents, myself included, could perhaps be classified as more radical constructionists. First of all, we are convinced by most of the ethnographic evidence old and new - the work of Robin Sherrif argues the opposite point of view (Sheriff 2001) - that the majority of Brazilians go about their everyday lives utilising a highly complex set of 'racial' taxonomies. (Bailey 2008, Baran 2007) Thus, we argue that racial quotas as a self-fulfilling prophecy could play an important role in bringing about the premise upon which they are based. Since these opponents see no positive future for 'racial consciousness', they advocate the destruction of the very concept of race.

Rita Segato has argued that "it seems acceptable that there are opinions, and that there are those who have opinions different from mine, but not that they 
present their opinion dressed up in the neutrality of a scientific argument. To agree or not to agree with a policy of quotas for Black students in Brazilian universities are two ideological positions in relation to society and the university, they are differences of points of view on what is better for the country. They are not the results of a disciplinary exercise." (Segato 2006)

Since Rita Segato threw the first stone ad hominem, here goes the return shot. Her view of the social life of anthropologists, rather akin to theories of rational choice, suggests that those men and women who do not agree with her act out of self-interest, bringing to bear their theory as ideology to conceal or justify their true intent. Thus, opponents of racial quotas are also generally accused of being white, elite and acting out of an interest to maintain their privilege. This is possible within the framework of a certain social science (or ideology?) which sees culture as handmaiden to practical reason. Another kind of anthropology which contemplates the complex interactions between culture and social action, suggests that theory and practice are mutually constituted, and, furthermore, that any 'native' should be taken seriously! Thus, speaking for myself, I understand that my terror of racism and all racialised theories and practices was born in my conversion to social anthropology in the 1960s and consolidated by my experience of racial segregation in colonial Southern Rhodesia, by my experience of racial odium in post colonial Zimbabwe and by my experience of a radically distinct arrangement of 'race' in contemporary Brazil, which for all its inequalities has at least avoided the building of distinct and antagonist 'racial' blocks. It is doubtful whether I would have reacted in the way I did had I not had this grounding in social anthropology. It is as clear as day to me that the imposition of racial categories by any state is bound to consolidate them first before the institutions of the state and ultimately in the subjectivity of its citizens. Similar narratives are told by my friends in this debate, not least those Jews whose constructionist sociology dovetails with their abhorrence of any recurrence of racial definition.

Not to disqualify the arguments of the proponents of racial quotas by suggesting any other reasons than those that they state, I must ask how their anthropology and their political stance become possible.

\section{A fer rorking hypotheses}

First of all, it cannot be without significance that some of the most outspoken principle anthropologists on both sides of the debate have researched what are generally termed Afro-Brazilian religions. José Jorge de Carvalho and Rita Segato have written extensively on Xango in Recife, Marcio Goldman about Candomblé (Goldman 1984), while Yvonne Maggie has written about Umbanda in Rio de Janeiro (Maggie 1975, 1992, 2001) and I about Umbanda in São Paulo and the Batuque of Belém (Fry 1976, 1986). Gabriel Banaggia, at the time a master's student at the PPGAS and member of the group pressing for quotas in that institution, tentatively suggested that there may be a certain relation between analytical postures vis-à-vis Afro-Brazilian and political attitudes in relation to racial quotas. The critics of quotas, he suggests, belong to an 'externalist' tradition which interprets Afro-Brazilian religion within the wider Brazilian context while supporters may be more closely linked to an 'internalist' tradition which 
concentrated on their continuity with Africa (Banaggia 2007). It is surely true that Yvonne Maggie and I, understanding ourselves to belong to a long lineage of 'externalists' beginning with Nina Rodrigues who was as fascinated by African continuity as he was with the sociology of candomblé in Bahia (Rodrigues 2007) have always been interested less in supposed African continuities than in their significance in contemporary Brazilian institutions. Although Goldman has adopted a predominantly 'internalist' stance (Goldman 1984), both Segato and Carvalho have been as fascinated by continuity with Africa as with the political and symbolic relevance of the religions in their contemporary social context (Carvalho 1993, Segato 1991).

But anthropology has always lived on the theoretical knife-edge of the universality of humankind and cultural diversity. Boas was responsible for debunking race but also for inaugurating what Marvin Harris termed historical particularism (Harris 1968). Cultural relativism became a shibboleth of those anthropologists who were and are cartographers of difference and diversity. And they are in great demand as 'diversity' emerges as the panacea for all our ills, be they from great capitalist corporations and philanthropies, be they from institutions of higher learning.

Among those who signed the manifestos in favour of quotas were a significant number of Brazilian anthropologists whose principal fieldwork has been undertaken with Amerindian peoples. It is possible that their particular concern with radical cultural difference and their political insistence on the need to maintain such ways of life may lend greater positive significance to the "social construction of difference". After all, much of the argument in defence of Amerindian rights in Brazil is based on their cultural specificity and its extreme longevity. As Adam Kuper has shown in his polemical essays on "the indigenous", social anthropology and its NGO allies have built on the notions of cultural relativity to form such groups as "Cultural Survival" whose title speaks for itself (Kuper 2003). When quotas are discussed for Amerindians, they are almost always justified on the basis that the Indians concerned will take their knowledge back to their 'communities' where it will be duly evaluated and incorporated or not into those communities' culturally defined goals and desires. Those anthropologists, therefore, from their indigenous perspective, are more likely than others to find notions of diversity and difference more plausible, even when applied to situations not in any way similar to those which they are acquainted. Other anthropologists, especially those involved in writing scientific reports for quilombo communities, also signed. They adhere to a notion that Brazil contains a culturally distinct Afro-Brazilian community. They may also have material interests at stake even though no-one seems to be able to tell me how much each report (laudo) costs. (The sudden upturn in interest in Afro-Brazilian studies after many decades of lowly academic status requires understanding.)

José Jorge de Carvalho often suggests that the university racial quotas will bring diverse knowledge to the university. This idea is shared by Otávio Velho, who, as I mentioned previously has defended diversity as if it had sprouted quite spontaneously, bringing new knowledge and challenging ancient colonialities (Velho 2007a, 2007b). I have suggested to him that he in fact preaches a departure from the coloniality of the Portuguese assimilationist Empire to the coloniality of an Empire built on the Dual Mandate of Lord Frederic Lugard and which celebrated not 
only ethnic inferiority and superiority, but, and above all, ethnic cultural specificity (Fry 2000). It is this form of 'coloniality', I would argue, that has spawned what is now called multiculturalism, if that be understood to mean the state-supported celebration of distinct "groups" and their so-called cultures. Here one must distinguish between multiculturalism and pluralism. The latter applies to the unselfconscious and un-authored co-existence of diverse groups within any nation state. The former refers to a formal policy based on a theory of cultural difference and designed to celebrate such differences by laws and state funding.

Finally, and here I tread on even more shaky ground or even quicksand, it may be possible that some anthropologists' adherence to the racial quotas has to do with another tradition of the discipline, namely to side not only with difference as a principle, but with that difference which is subordinate: an identification with the underdog.

With this I can more than sympathise. I share with most of my friends who are critical of the quotas a long-term commitment to the elimination of all forms of prejudice and discrimination and would prefer to see a drastic reduction in all forms of inequality in Brazil. A massive investment in quality public education would rapidly change the overall colour of Brazil's public university students without ever having to invoke "race" to do so. It is increasingly difficult to maintain what we understand to be a radical long-term anti racist posture which involves head on collision with the short term goals of the black activists and their allies, who are committed to the social mobility of Brazil's darker citizens through the celebration of racial identities and who attribute to us critics the basest of motives. I take heart in thinking that doubt is nearer to the heart of social anthropology than conviction.

\section{Fuly 2009 \\ Peter FRY}

Universidade Federal do Rio de Janeiro

Instituto de Filosofia e Giências Sociais

\section{References}

Anjos, J.C. dos 2005, "O tribunal dos tribunais: onde se julgam aqueles que julgam raças", Horizontes Antropológicos (Porto Alegre), 11: 232-236.

Bailey, S. R. 2008, "Unmixing for Race Making in Brazil", American fournal of Sociology (University of Chicago Press), 114: 577-614.

BANAGgia, G. 2007, "Essencial, meu caro Watson: sobre alguns programas de (des)essencialização", Fornada conjunta de alunos dos Programas, Programa de Pós-Graduação em Sociologia e Antropologia (Instituto de Filosofia e Ciências Sociais IFCS da Universidade Federal do Rio de Janeiro) e Programa de Pós-Graduação em Antropologia Social (Museu Nacional) e Programa de PósGraduação em Sociologia e ciências politica (Instituto Universitário de Pesquisas do Rio de Janeiro), Rio de Janeiro, IFCS/UFRJ.

Baran, M.D. 2007, “'Girl, You Are Not Morena. We Are Negras!': Questioning the Concept of 'Race' in Southern Bahia", Brazil, Ethos (Arlington, VA), 35: 383-409.

Bortoloni, M.C. 2005, "A genética e a peritagem racialista", Horizontes Antropológicos, 11: 262263.

Carvalho, J.J. de 1993, Cantos Sagrados do Xangô do Recife, Brasília, Fundação Cultural Palmares. 
2005, "Usos e abusos da antropologia em um contexto de tensão racial: o caso das cotas para negros na UnB", Horizontes Antropológicos, 11: 237-244.

Carvalho, J.J. de \& Segato R. 2002, "Uma proposta de cotas para estudantes negros na Universidade de Brasília. Apelo a toda a comunidade universitária e em particular aos seus representantes no Conselho de Ensino, Pesquisa e Extensão (CEPE) para que compreendam o problema da ausência de estudantes negros no ensino superior brasileiro e aceitem implementar, em caráter urgente, medidas que ajudem a reverter esse quadro crônico de exclusão (com uma exortação para que se formule em seguida uma proposta específica de implementação de vagas para índios)", Série Antropologia (Universidade de Brasília), 314.

Duarte, L.F.D. 2006, "Pungente retrato do universalismo apunhalado", in C. Steil (ed.), Cotas raciais na universidade: um debate, Porto Alegre, Universidade Federal do Rio Grande do Sul (UFRGS).

Freyre, G. 1961, Portuguese Integration In The Tropics, Lisbon, Agencia Geral do Ultramar.

FrY, P. 1976, "Feijoada e Soul Food: notas sobre símbolos étnicos e nacionais", Ensaios de Opinião (Rio de Janeiro), 4.

- 1986, "Male Homosexuality and Spirit Possession in Brasil", fournal of Homosexuality (New York, Haworth Press), 11: 137-154.

— 2000, "Cultures of Difference: the aftermath of Portuguese and British colonial policies in Southern Africa", Social Anthropology (European Association of Social Anthropologists, Stocklom), 8: 117-144.

_ 2004, "A lógica das cotas raciais", O Globo (Rio de Janeiro): 7.

_ 2005, A persistência da raça: ensaios antropológicas sobre o Brasil e a África austral, Rio de Janeiro, Civilização Brasileira.

Fry, P., Y. Maggie, M.C. Maio, S. Monteiro, \& R.V. Santos, eds 2007, Divisões Perigosas: politicas raciais no Brasil contemporâneo, Rio de Janeiro, Civilização Brasileira.

Goldman, M. 1984, "A Possessão e a Construção Ritual da Pessoa no Candomblé”, mestrado, Universidade Federal do Rio de Janeiro.

2007, "Obra silencia sobre lutas dos minoritários", Folha de S. Paulo (São Paulo).

Grin, M. 2006, Estatuto da Igualdade Racial: Uma Questão de Princípio, Ciência Hoje (Rio de Janeiro), 38: 56-58.

Hacking, I. 1999, The Social Construction of What?, Cambridge-Massachusetts-London, England Harvard University Press.

Harris, M. 1968, The Rise of Anthropological Theory: A History of Theories of Culture, New York, Thomas Y. Crowell Company.

Harris, M., J. Gomes, Lang, J., \& Byrne, B. 1993, "Who are the Whites?: Imposed Census Categories and the Racial Demography of Brasil", in Social Forces (University of North Carolina), 72.

Htun, M. 2004, "From racial democracy to affirmative action: changing state policy on race in Brazil", Latin American Research Reviere, 39: 60-89.

Kuper, A. 2003, "The Return of the Native", Current Anthropology, 44: 389-402.

Lewgoy, B. 2005, "Cotas raciais na UnB: as lições de um equívoco", Horizontes Antropológicos, 11: 218-221.

2007a, "Não às cotas raciais na UFRGS", Zero Hora (Porto Alegre).

2007b, "Um tribunal racial para a UFRGS?," Correio do Povo (Porto Alegre).

Maggie, Y. 1975, Guerra de orixá: um estudo de ritual e confito. Biblioteca de Antropologia social, Rio de Janeiro, Zahar.

— 1992, Medo do Feitiço: Relações Entre Magia e Poder no Brasil, Rio de Janeiro, Ministério da Justiça.

— 2001, "Fetiche, feitiço, magia e religião", in N. Esterci, P. Fry \& M. Goldenberg (eds), Fazendo Antropologia no Brasil, Rio de Janeiro, DP\&A.

— 2008, "Does Mário de Andrade Live On? Debating the Brazilian Modernist Ideological Repertory", Vibrant - Virtual Brazilian Anthropology (Brasília): 34-64. 
Maio, M.C. \& Santos, R.V. 2005, "Políticas de cotas raciais, os olhos da sociedade e os usos da antropologia: o caso do vestibular da Universidade de Brasília (UnB)", Horizontes Antropológicos, 23:181-214.

NogueIra, O. 1959, "Skin color and social class", in General Sectretariat Organization of American States, ed., Plantation Systems of the New World, Social Science Monographs, Washington, D.C., Research Institute for the Study of Man and the Pan American Union.

Paim, P. 2006, Estatuto da Igualdade Racial, Brasília, Senado Federal.

Pena, S.D. 2005, "O triste caso do vestibular da Universidade de Brasília", Horizontes Antropológicos, 11: 283-285.

Ribeiro, G.L. 2006, "Tirando alguns esqueletos do armário acadêmico", in C. Steil, Cotas raciais na universidade um debate, Porto Alegre, Editora UFRGS.

Rodrigues, R. Nina 2007 [1896-97], O animismo fetichista dos negros baianos. Edição facsimile com apresentação e notas de Yvonne Maggie e Peter Fry, Rio de Janeiro, Fundação Biblioteca Nacional - UFRJ Editora.

Salzano, F.M. 2005, "Raça, racismo e direitos humanos", Horizontes Antropológicos, 11: 223-227.

SAnsone, L. 2006, "O bebê e a água do banho - a ação afirmativa continua importante não obstante os erros da UnB!”, in C. Steil (ed.), Cotas raciais na universidade um debate, Porto Alegre, Editora UFRGS.

Segato, R.L. 1991, "Uma Vocação de Minoria: A Expansão dos Cultos Afro-Brasileiros na Argentina como Processo de Reetnicização", Dados - Revista de Ciências Sociais (Rio de Janeiro, IUPERJ), 34.

— 2006, "Em memória de tempos melhores: os antropólogos e a luta pelo direito", Horizontes Antropológicos, 11.

Seyferth, G. 1996, "Construindo a Nação: hieraquias raciais e o papel do racismo na política de imigração e colonização", in M.C. Maio \& R.V. Santos (eds), Raça, Ciência e Sociedade, Rio de Janeiro, Editora Fiocruz.

Sheriff, R.E. 2001, Dreaming Equality Color, Race and Racism in Urban Brazil, New Brunswick-New Jersey-London, Rutgers University Press.

Spivak, G.C. 1990, Interviewes, Strategies, Dialogues, New York, Routledge.

Sztutman, R., ed. 2008, Eduardo Viveiros de Castro, Rio de Janeiro, Beco do Azougue.

Velho, O. 2007a, "À cata das cotas", Inteligência (Rio de Janeiro): 125-134.

2007b, Alguns temas em torno e além da questão das cotas e das ações afirmativas, Porto Alegre, Associação dos Docentes da Universidade Fderal do Rio Grande, <www.adufrgs.org.br/ conteudo/sec.asp?id=cont_adverso.asp\&InCdMateria=1012>, accessed 28 october 2007. 


\section{CREATIONS EN MIGRATIONS PARCOURS, DEPLACEMENTS, RACINEMENTS}

\section{Coordination :}

\section{Marco Martiniello, Nicolas Puig et Gilles Suzanne}

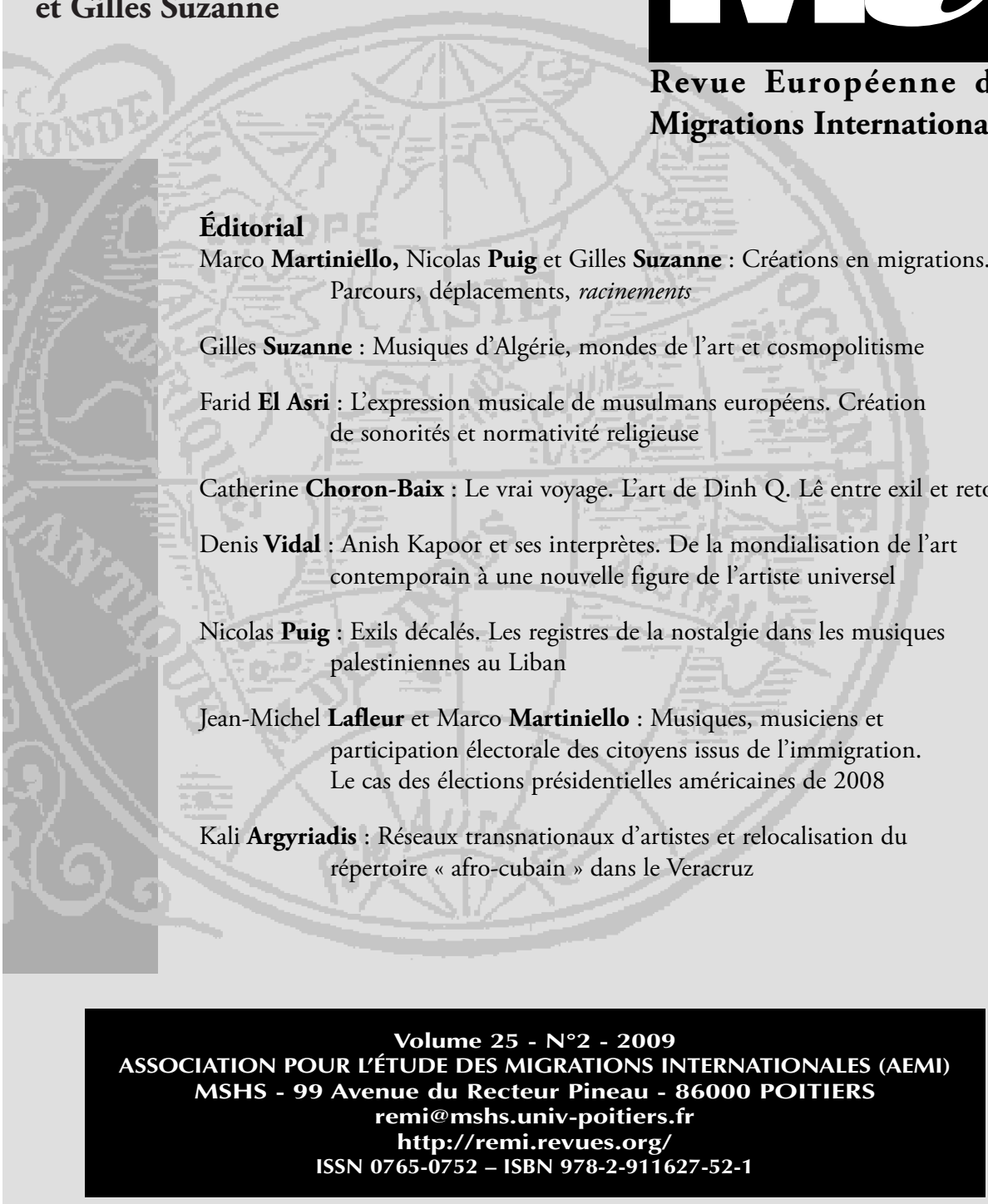

Éditorial

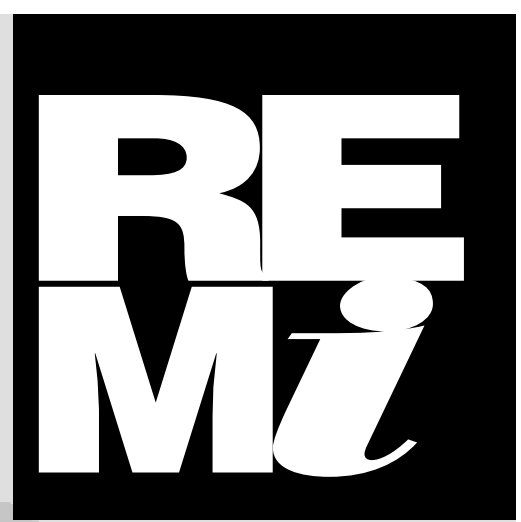

Revue Européenne des Migrations Internationales 